\title{
The shapes of verbal paradigms in Kiranti languages
}

\begin{abstract}
Aimée Lahaussois *
The Kiranti languages of Eastern Nepal have polypersonal indexation, with two arguments encoded in verb agreement markers. In contemporary descriptions of Kiranti languages (from 1975 on), the tables presenting transitive verb paradigms are arranged according to the same layout, in a matrix format with the different person/number combinations for the agent argument represented in the vertical axis and the patient argument person/number combinations in the horizontal axis. In earlier grammars, however, a number of different formats for representing the combination of two arguments was used. In this article, I shall present the different paradigm formats found in a sampling of grammars of Kiranti languages from 1857 to the present day, with a view to tracing the origins of the current layout, and, in cases where significantly different layouts are encountered, attempting to retrace the model which may have influenced the presentation of the data.
\end{abstract}

\section{INTRODUCTION}

The notion of extended grammar and grammaticographical transfer can be challenging to apply to the description of languages without an indigenous or even local grammatical tradition. There are nonetheless methods which can be applied to such languages in order to identify how the grammar has been shaped. One such method is to look at successive descriptions of a single language or languages across a geographical area in order to identify what has been transferred.

Verbal morphology is a particularly interesting domain to explore in an attempt to find traces of grammatical models, especially for the Kiranti languages of Nepal, as they share an areally marked feature, namely the indexation of two arguments on transitive verbs. Grammarians attempting to describe the Kiranti languages are confronted with the question of how to present such data, both descriptively and representationally.

Through a sampling of descriptions of Kiranti languages from 1857 to 2015, I will concentrate on the following two issues, in order to determine what models were used for the presentation of finite verb forms and how the layouts spread from grammar to grammar:

1) What layout is used for verbal paradigms for transitive verbs indexing two arguments, both in terms of physical presentation and axial ordering of argument person/number

2) What is the degree of explicitness about the layout and related terminology: is it taken for granted that the paradigm will be understood correctly, or are there explanations for its use (including mention of the gaps that appear for certain person/number combinations)?

\section{THE GRAMMARS}

The 30-some Kiranti languages form a subgroup of the Tibeto-Burman family, and are spoken in Eastern Nepal. They are largely oral languages, with no indigenous or local grammatical tradition.

There are a number of grammars and shorter descriptions of Kiranti languages, some of them centered around 'schools', and others independent: the Himalayan Languages Project, originally based in Leiden and currently in Bern, has generated more than a dozen of these grammars under the supervision of George van Driem. Another group, centered around Balthasar Bickel and the University of Zurich, has also produced wellrespected descriptions. In addition to the work produced by these groups, there are also grammars or descriptive articles by linguists working independently of each other at various institutions.

The grammars which will be examined are presented in chronological order:

Vayu Vocabulary, B. Hodgson 1857

Bahing Vocabulary, B. Hodgson 1857, 1858.

The Khaling Verb, I. Toba 1973

Sketch of Thulung Grammar, N. J. Allen 1975

A Grammar of Limbu, G. van Driem 1987 \footnotetext{
* Laboratoire Histoire des théories linguistiques, CNRS/Université Paris Diderot, I wish to thank 3 anonymous reviewers for very insightful comments, the Labex EFL, and a CNRS-University of Melbourne PRC project "Chains of Influence in Himalayan grammars".
} 
La langue hayu, B. Michailovsky 1988

A grammar of Jero, J.-R. Opgenort 2005

A grammar of Bantawa, M. Doornenbal 2009

A grammar of Yakkha, D. Schackow 2015

Additional descriptions could have been added to this list, but due to the volume of available material, I have limited the sample to the above, which I believe to be representative of the types of grammars found for Kiranti languages.

\section{1857-1975: PERIOD OF VARIED APPROACHES TO LAYING OUT VERBAL PARADIGMS}

In an article called Vayu Vocabulary in an 1857 volume of the Journal of the Asiatic Society of Bengal, Hodgson provides the first known description of the grammar of the Vayu language. This description includes a presentation of verbal morphology, accompanied by verb paradigms. The following illustration is of one such conjugation table made up of unsegmented verb forms, organized according to tense ('present or future' vs 'preterite', although only the present/future is shown in Ill. 1 below) and to the number of the subject (singular, dual, plural, the latter two of which can be either inclusive or exclusive for non-singular 1st persons).

\section{Indieative Mood. \\ Present or future.}

Singular.

1. Hátungmi.

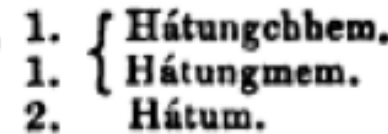

2. +Hátochhem.

2. +Hatomem.

3. +Hátum.

3. +Hátorhbem. 3. +Hátomem.

Singular.

1. Sinmi.*

1. Bincbhem.

1. Sinmem.

2. +Sitmi.

2. Sischbikmi.

2. Sitmem.

3. + Sitmi. $\uparrow$
Dwal.

$\left\{\begin{array}{l}\text { +Háchhokmi, exel. } \\ \text { +Háchbikmi, incl. }\end{array}\right.$

Dual and Plural of Object.
I give to them two.

I give to them all.

+Hichbikmi.

Dual and Plural of Object.

Thou givest to them two.

Thou givest to them all.

+Hátochbem.

\section{Dual and Plural of Object.}

He gives to them two.

He gives to them all.
Plural.

$\{$ Hátikokmi, excl. Hátikem, incl.

+Hánem.

+Hátomem.

\section{Indicative present.}

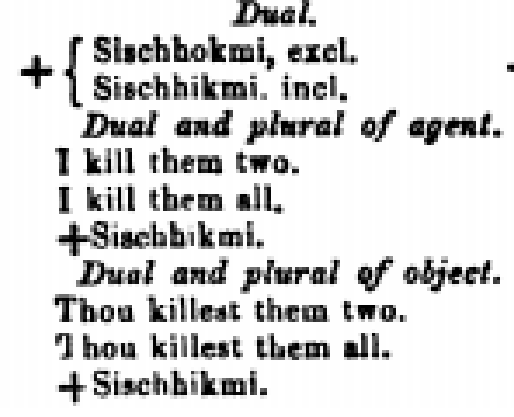

Phural.

$+\left\{\begin{array}{l}\text { Sitkokmi, exd. } \\ \text { Sitkem, inel. }\end{array}\right.$

+Sitnem.

+Sitmew.

Dual and plural of object.

3. +Sischhikmi.

3. +Sitmem.

He kills them two.

He kills them all.

Illustration 1 (Hodgson 1857:448-449), transitive verb 'to kill'

More schematically, the conjugation table presents the forms for the person/number combinations laid out below (approximating the positions of these forms in Illustration 1): 


$\begin{array}{lll}1 \mathrm{SG}(>3 \mathrm{SG})^{1} & \begin{array}{l}1 \mathrm{DE}(>3 \mathrm{SG}) \\ 1 \mathrm{DI}(>3 \mathrm{SG})\end{array} & \begin{array}{l}1 \mathrm{PE}(>3 \mathrm{SG}) \\ 1 \mathrm{PI}(>3 \mathrm{SG})\end{array} \\ \begin{array}{l}\mathrm{SG}>(3) \mathrm{DU} \\ 1 \mathrm{SG}>(3) \mathrm{PL}\end{array} & \\ 2 \mathrm{SG}(>3 \mathrm{SG}) & 2 \mathrm{DU}(>3 \mathrm{SG}) & 2 \mathrm{PL}(>3 \mathrm{SG}) \\ 2 \mathrm{SG}>(3) \mathrm{DU} & & \\ 2 \mathrm{SG}>(3) \mathrm{PL} & 3 \mathrm{SG}(>3 \mathrm{SG}) & 3 \mathrm{PL}(>3 \mathrm{SG}) \\ 3 \mathrm{SG}(>3 \mathrm{SG}) & & \end{array}$

The object is taken to be 3SG by default, unless a different number is specified, in which case the object number is conveyed through a heading ("Dual and Plural of Object") and a free translation of the forms (possibly due to the non-transparent nature for readers at the time of a form involving a non-singular object). The person of the subject is given in numerical shorthand $(1,2,3)$. As we can see from this layout, there is no 'slot' for dual or plural subjects combining with dual or plural objects. There is also no slot, at least in this part of the paradigm, for objects other than 3rd persons. ${ }^{2}$

Despite the gaps in some person/number combinations, and the, to modern eyes, unusual treatment of inverse forms, the system is quite ingenious as a first attempt to lay out data that changes along two axes. Nonetheless, partway through the article, Hodgson comes up with a better organization system, which he describes as follows:

"The above fifteen conjugations with their accessories [...] exhibit the whole scope of Vayu conjugation. But a reference to them will show that it has been necessary, whilst striving to accommodate our forms to the genius of this language, to interpolate into the transitives certain forms expressive of both agent and object, and likewise to append to the passive certain other forms which have been necessarily set apart from all the conjugations; not to mention the perpetual coincidence of active and passive forms. It may now be of use to the exhibit the whole matter of conjugation in another shape seemingly more accommodated to the genius of the language, and which, though exhibiting a deal of repetition, will be found convenient for comparisons when we procees to the Kiranti language, a language still richer than the Vayu tongue, in pronominal combinations with the verb and wherein consequently many of the mere iterations of the following diagram will take distinct shapes" (1857: 470)

He then proceeds (1857: $471 \mathrm{ff})$ to present the verbs again, in a different type of layout which I will refer to as the "list paradigm" ${ }^{3}$.

\footnotetext{
${ }^{1}$ Hereafter, $>$ is used to indicate that the person/number combination to the left of the symbol is the subject, and the person/number combination to the right is the object. One also finds $\rightarrow$ used in the same way in some Kiranti grammars (van Driem 1987, Opgenort 2005, Doornenbal 2009, among others).

2 Only direct forms--those where the subject ranks higher than the object in a $1>2>3$ hierarchy--are presented here; Hodgson presents inverse forms, the opposite of direct forms, involving a 3rd person object in the "passive" part of his verb conjugation, and has a separate section, labeled "special" forms, for $1>2$ and $2>1$ verb forms.

3 This term stands in opposition to the "matrix paradigm," which will come to dominate later.
} 


\section{Indicative Mrood.}

\section{Present and Future.}

\section{Singular.}

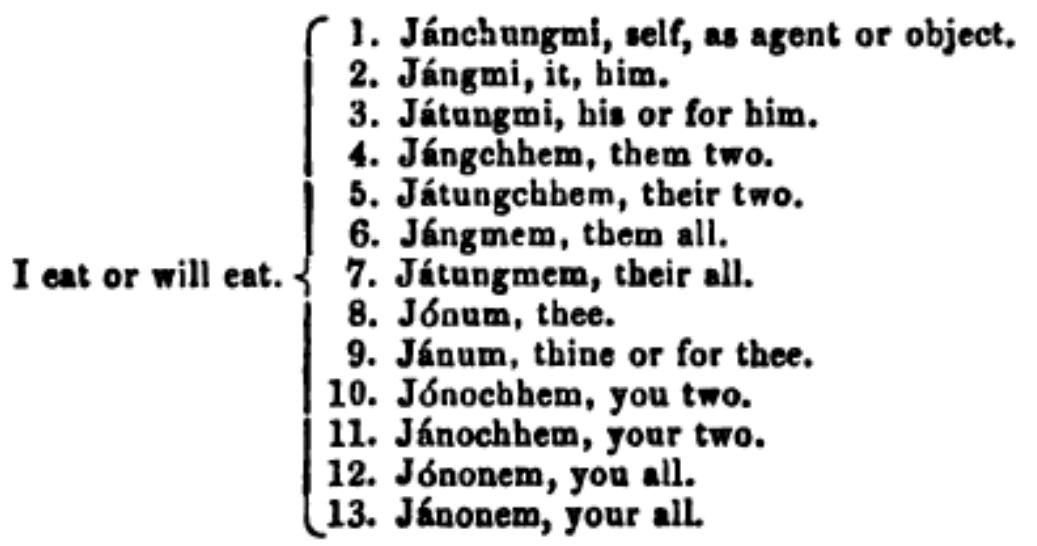

Dwal.

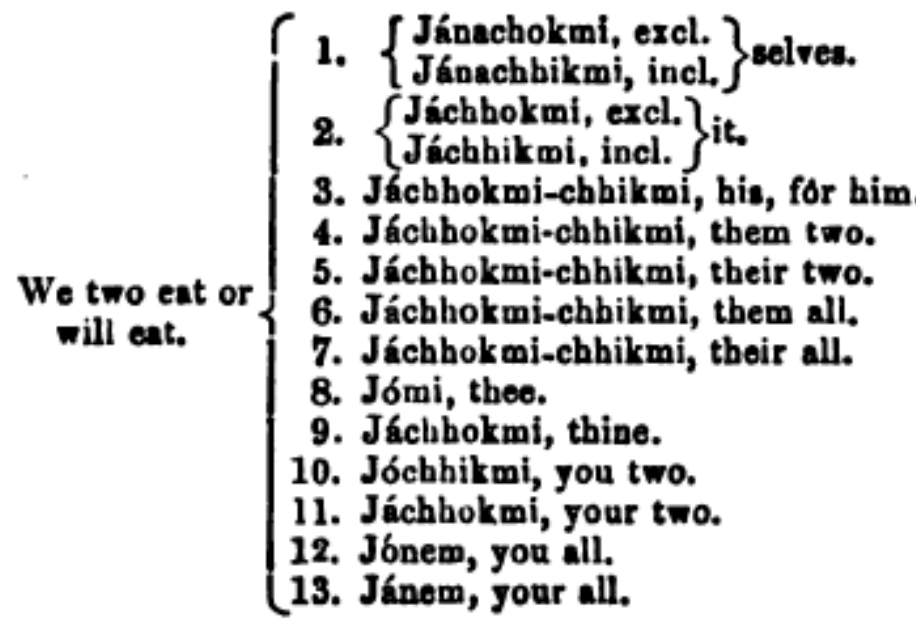

Plunal.

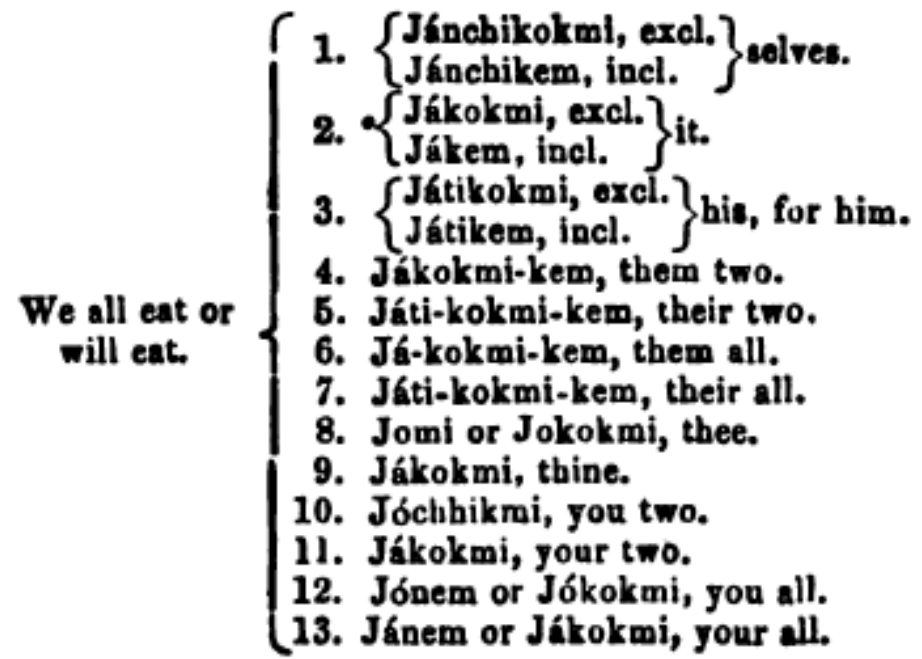

Illustration 2 (Hodgson 1857: 472-475)

In the interest of brevity, only a partial rendition of the conjugation is shown in Illustration 2. Schematically, the order of the forms is as follows, with all combinations of subject and object given in turn: 


$\begin{array}{ll}\text { subject: } & \text { object: } \\ \text { 1SG } & \text { reflexive } \\ \text { 1DI } & 3 \mathrm{SG} \\ \text { 1PI } & 3 \mathrm{DU} \\ \text { 2SG } & 3 \mathrm{PL} \\ \text { 2DU } & 2 \mathrm{SG} \\ \text { 2PL } & 2 \mathrm{DU} \\ 3 \mathrm{SG} & 2 \mathrm{PL} \\ \text { 3DU } & 1 \mathrm{SG} \\ \text { 3PL } & 1 \mathrm{DI} / \mathrm{DE} \\ & 1 \mathrm{PI} / 1 \mathrm{PE}\end{array}$

The inverse forms, originally redistributed into 'passive' and 'special' sections of the conjugations, are here incorporated into a single paradigm, and all possible combinations of person and number for both subject and object are taken into account, something which was not the case with the original presentation.

The presentation, even in its new set-up, relies on translation rather than metagrammatical glosses, but as we shall see, this new organization in the form of a list, with subject/object combinations presented in a consistent order, has had a lasting impact and is still used in some recent grammars.

One point of interest is the order in which the object is treated: this is in the order 3-2-1, whereas current practice for Kiranti descriptions is the order 1st, 2nd, then 3rd person. Hodgon's order of treatment of the object is however found in a grammar of Maithili (Yadav 1996: $174 \mathrm{ff}$ ), in which the whole paradigm is organized according to 3-2-1 order for both subject and object.

By the following year (1858, vol 27 of Journal of the Asiatic Society of Bengal) the presentation used for verb paradigms in Hodgson's Bahing grammar is somewhat different, in that it is more analytical: a) the morphemes making up the verb forms are separated by hyphens (this was not the case for the Hayu data), and

b) the use of numbers identifying the verb forms refers no longer to the person of the subject, but rather to a slot within a table of subject/object combinations as set up earlier. 


\section{INDICATIV Mood.}

\section{Present and Future Tonses.}

Singular of Agent.

Dual of Agent.

Plural of Agent.

Firut Person.

1. $\left\{\begin{array}{l}\text { J6-gna, I eat or will } \\ \text { eat it. }\end{array}\right.$

1. $\left\{\begin{array}{c}\text { J6-sa, inelusive. } \\ \text { Ja-suku, excluaive. } \\ \text { We two eat it. }\end{array}\right.$ 1. $\left\{\begin{array}{c}\text { JG-ya, inclusive. } \\ \text { J6-ka, exclusive. } \\ \text { Wo all ent it. }\end{array}\right.$

Dwal of Object.

Dwal of Object.

Dwal of Objeet.

2. $\left\{\begin{array}{l}\text { Ja-gna-si, } \\ \text { I eat them two. }\end{array}\right.$

2. $\left\{\begin{array}{l}\text { Ja-ea-si, inclusive, } \\ \text { Ja-sukusi, exclusive, } \\ \text { We two eat them } \\ \text { two. }\end{array}\right.$

Plural of Object.

2. $\left\{\begin{array}{l}\text { Já-ya-si, inclusive. } \\ \text { Jt-ka-si, exclasire. } \\ \text { We all eat them } \\ \text { two. }\end{array}\right.$

Plural of Object.

3. $\left\{\begin{array}{l}\text { Ja-sa-mi, inclusire, } \\ \text { Ja-nuku-mi, excl. } \\ \text { We two eat them } \\ \text { sll. }\end{array}\right.$

3. $\left\{\begin{array}{l}\text { Ja-gaa-mi, } \\ \text { I eat them all. }\end{array}\right.$ Plwral of Object.

Second Person.
1. Jh-(y) f.
2. Já-(y)-i-si.
1. Jh-ni.
2. Já-si-si.
3. Jk-si-mi.
1. Ja-ni.
2. Ja-ni-ni.
3. J6 (y)-i-mL.

Third Pereon.

1. Ja-wa.

2. J6-wa-si.

1. Ján-se.

2. Já-se-si.

3. $\left\{\begin{array}{l}\text { Ja-yami, inel. } \\ \text { Ja-ka-mi, excl. } \\ \text { Wo all eat them } \\ \text { all.* }\end{array}\right.$

3. Já-wa-mi.

3. Já-se-mi.

1. Jk-me.

8. Já-me-si.

3. Ja-me-mi.

Illustration 3 (Hodgson 1858: 407-408) 
Whereas for Vayu, the numbering next to the verb forms was for the person of the subject, here the numbering appears to correspond, within a heading specifying the person of the subject, to the number of the object. ${ }^{4}$ This presentation has a number of advantages:

a) the resulting grid-like format ensures that no forms are left out (cf. the Vayu data which omitted only listed singular agents with dual or plural objects, Ill. 1) b) the data is easier to compare across forms: it is easier to analyse the import of specific morphemes with a presentation where the forms with the same object number are labeled the same way.

c) the (partial) removal of glossing (again, cf. the Vayu data in Illustration 1) from the lists of forms suggests that the presentation is analytical enough that it does the job of the translation.

The forms in Illustration 3 above are those for the first transitive verb ('eat') which is presented in the grammar; subsequent verbs are presented even more analytically: the number of the object is no longer made explicit textually (cf Illustration 3 where in addition to the number of the object we also had labels 'dual of object', 'plural of object') as the numbering alone is considered sufficient, and translations are virtually absent. However, so are morpheme breaks: ${ }^{4}$ As with the Vayu description, unless otherwise specified the person of the
object is a default 3rd person. 


\section{Indicative Mood.}

\section{Present and Future Tonse.}

\section{Firat person.}

1. Brétú,

2. Brétusi.

3. Brétúmi.
1. Bréti.
2. Brétisi.
3. Brétimi.

1. Bréta.

2. Brétasi.

3. Brétami.
1. $\left\{\begin{array}{l}\text { Brétisu, incl. } \\ \text { Brétisuka, excl. }\end{array}\right.$

2. $\left\{\begin{array}{l}\text { Brétisasi. } \\ \text { Brétisukusi. }\end{array}\right.$

3. $\left\{\begin{array}{l}\text { Brétisami. } \\ \text { Brétisulumi. }\end{array}\right.$

Second person.

1. Brétisi.

2. Brétisisi.

3. Brétisimi.

\section{Third person.}

1. Brétise.

2. Bretisesi.

3. Bretisemi.
1. $\left\{\begin{array}{l}\text { Brétiya, incl. } \\ \text { Brétika, excl. }\end{array}\right.$

2. $\left\{\begin{array}{l}\text { Brétiyasi. } \\ \text { Brétikasi. }\end{array}\right.$

3. $\left\{\begin{array}{l}\text { Brétiyami. } \\ \text { Brétikami. }\end{array}\right.$

1. Brétini.

2. Brétinisi.

3. Brétinimi.

1. Brétime.

2. Brétimesi.

3. Brétimémi.

Illustration 4 (Hodgson 1858: 421)

There seems to be, during the short period from 1857 to 1858 , a clear transition from a more descriptive presentation of verbal morphology, making use of free translation and unsegmented forms, towards a more paradigmatic presentation, where the numbering and position of cells is sufficient for the identification and analysis of forms, without resorting to glosses, translations, or explanations.

Hodgson's work is followed by a very long gap during which there were, to my knowledge, no English-language grammatical descriptions of Kiranti languages. This period of grammatical drought ended with work on Khaling by Ingrid and Sueyoshi Toba in the 1970's.

I. Toba's 1973 article "The Khaling verb", which is quite short at 13 pages, discusses the verb stem alternations and personal suffixes needed for conjugating verbs in Khaling. Illustration 5 shows the paradigm of personal suffixes. 


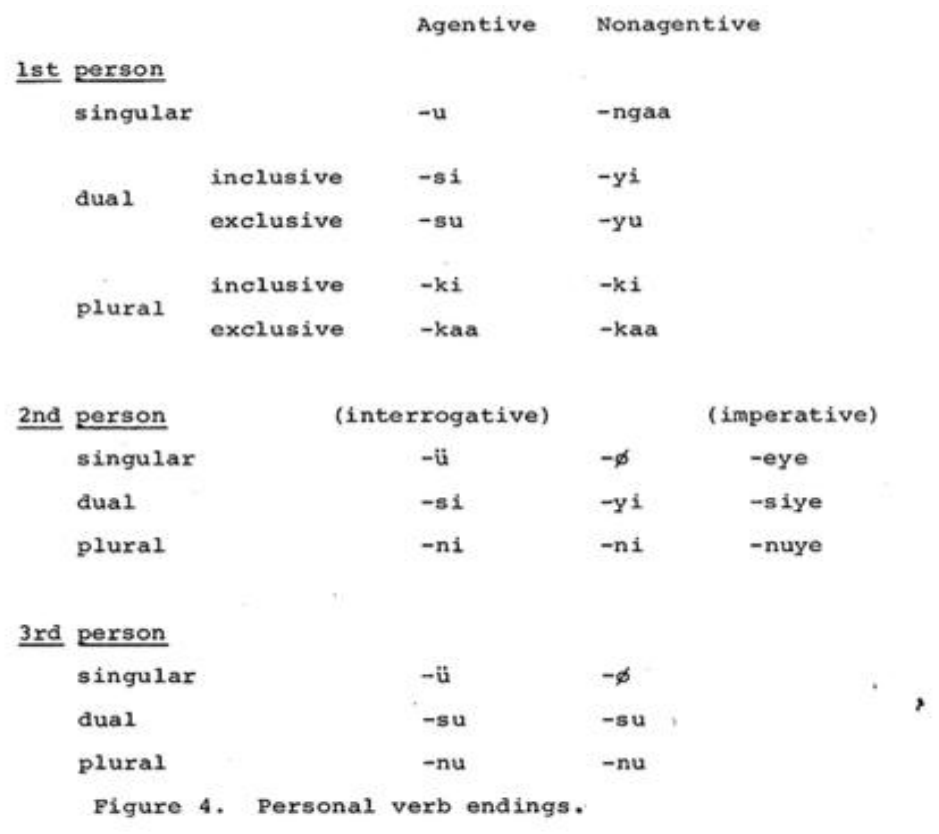

Illustration 5 (Toba 1973: 11)

The data is presented in a table where various possibilities for the person/number of subject intersect with features labeled 'agentive' and 'nonagentive'. These terms are ambiguous: the most likely interpretation is that they are to be interpreted as refering to transitive and intransitive affixes respectively. But considering the structure of Khaling verb morphology, intransitive suffixes in some cases have the same form as object-marking suffixes for transitive verbs (only when the subject is 3SG): the suffix -ngaa ("1st person singular nonagentive)" in Ill. 5 above marks both a 1 SG object and a 1 SG intransitive subject, so it is possible that Toba uses the label 'nonagentive' in her tables to list suffixes that mark both $\mathrm{S}$ and $\mathrm{P} .{ }^{5}$

If the second interpretation is correct, then certain scenarios (dual or plural subjects, 1>2 and 2>1) cannot be expressed by the paradigm, as the layout does not provide slots for such combinations. If instead (and more likely), the first interpretation is correct and the two columns present the suffixes for transitive and intransitive verbs for each person/number combination of subject,

\footnotetext{
${ }^{5}$ As will be described later, Schackow's (2015) inclusion of intransitive forms into transitive paradigms is partly to illustrate this symmetry between transitive $\mathrm{P}$ marking and intransitive $\mathrm{S}$ marking.
} 
then we have a different problem: the transitive forms assume a default $3 \mathrm{sg}$ object $^{6}$ (as did Hodgson in his original paradigms for Vayu), and there is no possibility for generating any other combinations (such as, for example, a $1 \mathrm{sg}$ subject acting on a $3 \mathrm{du}$ object) from the data in the table.

From the paradigm as presented above, it is not clear to what extent Toba was aware of the need to mark objects on transitive verbs in Khaling, despite a statement on page 3 of the article to that effect: «Agreement between person and number for subject as well as for object is indicated everywhere except 3rd person singular » (1973: 3 ). The fact that object agreement is taken up nowhere else in the article suggests that the citation I give is possibly the result of a last-minute revision to the article.

Is it possible that a traditional grammar framework, developed for languages without object agreement and therefore ill-suited for polypersonal indexing paradigms, made it difficult for Toba to see the necessity of presenting affixes indexing objects in transitive scenarios; similarly the presentation of only suffixes, despite the crucial role of prefixes in Khaling verbal morphology (Jacques et al 2012), suggests either oversight or preconceived, probably European-language influenced, ideas about paradigms that interfered with the reality of the Khaling language. ${ }^{8}$

In the transition from Hodgson to Toba, a few points are to be noted: we find the assumption of a default $3 \mathrm{sg}$ object in both presentations of verbal paradigms, although in Hodgson there are slots, even though they are oddly labeled ('passive', 'special forms'), for objects of different person/number, and in his later paradigms, a reversal of the default $3 \mathrm{sg}$ object approach.

\section{1975: THE EMERGENCE OF MATRIX PARADIGMS}

In the Sketch of Thulung Grammar, written by Allen in 1975, we see a very different type of paradigm layout emerge. The paradigm is based on two axes for the two arguments (while Allen consistently uses the terms subject/object in the text, the labels Causer Case and Affected Case are used in transitive paradigms), as in Illustration 6 below. I will label these "matrix paradigm", following Pike 1962.

${ }^{6}$ This is statistically the most frequent person/number combination for an object (as any non-plural noun will be encoded as $3 \mathrm{sg}$ ).

7 A few other problems with the paradigm must be noted, in terms of their potential for generating any possible form: No mention is made of prefixes, even though these are essential for distinguishing forms with a 2nd or 3rd person S or A; Prefixes are also needed to mark inverse forms (where A is "lower" than P in the $1>2>3$ person hierarchy); The existence of past forms is not acknowledged. ${ }^{8}$ Note that the first grammar of an Algonquian language, written in 1666 by John Eliot, is similar in this respect: only suffixes are presented, whereas the paradigms show Eliot is clearly aware of the prefixes necessary for person marking. 


\begin{tabular}{|c|c|c|c|c|c|c|c|c|c|c|c|c|}
\hline \multirow{2}{*}{\multicolumn{2}{|c|}{ of $\mathrm{Cs}$}} & \multicolumn{5}{|c|}{ 1st person } & \multicolumn{3}{|c|}{ 2nd person } & \multicolumn{3}{|c|}{$3^{\text {rd person }}$} \\
\hline & & sing & $\begin{array}{l}\text { incl } \\
\text { dual }\end{array}$ & $\begin{array}{l}\text { incl } \\
\text { plur }\end{array}$ & $\begin{array}{l}\text { excl } \\
\text { dual }\end{array}$ & $\begin{array}{l}\text { excl } \\
\text { plur }\end{array}$ & sing & dual & plur & sing & dual & plur \\
\hline \multirow[t]{5}{*}{ 1st } & sing & & & & & & $\begin{array}{l}\mathrm{ni} \\
\mathrm{ni}\end{array}$ & $\begin{array}{l}\text { nici } \\
\text { nici }\end{array}$ & $\begin{array}{l}\mathrm{ni} \\
\mathrm{ni}\end{array}$ & $\begin{array}{l}\mathrm{u} \\
\text { to }\end{array}$ & $\begin{array}{l}\text { uci } \\
\text { toci }\end{array}$ & $\begin{array}{l}\text { umi } \\
\text { tomi }\end{array}$ \\
\hline & incl dual & & & & & & & & & $\begin{array}{l}\mathrm{ci} \\
\mathrm{ci}\end{array}$ & $\begin{array}{l}\mathrm{ci} \\
\mathrm{ci}\end{array}$ & $\begin{array}{l}\text { ci } \\
\text { ci }\end{array}$ \\
\hline & incl plur & & & & & & & & & $\begin{array}{l}\text { i } \\
\text { li }\end{array}$ & $\begin{array}{l}\text { i(ci) } \\
\text { li(ci) }\end{array}$ & $\begin{array}{l}\mathrm{i}(\mathrm{mi}) \\
\mathrm{li}(\mathrm{mi})\end{array}$ \\
\hline & excl dual & & & & & & $\begin{array}{l}\text { naci } \\
\text { naci }\end{array}$ & $\begin{array}{l}\text { naci } \\
\text { naci }\end{array}$ & $\begin{array}{l}\text { nicimi } \\
\text { nicimi }\end{array}$ & $\begin{array}{l}\text { cuku } \\
\text { coko }\end{array}$ & $\begin{array}{l}\text { cuku } \\
\text { coko }\end{array}$ & $\begin{array}{l}\text { cuku } \\
\text { coko }\end{array}$ \\
\hline & excl plur & & & & & & $\begin{array}{l}\text { nami } \\
\text { nami }\end{array}$ & $\begin{array}{l}\text { nacimi } \\
\text { nacimi }\end{array}$ & $\begin{array}{l}\text { nimi } \\
\text { nimi }\end{array}$ & $\begin{array}{l}\text { ku } \\
\text { toko }\end{array}$ & $\begin{array}{l}\text { ku } \\
\text { toko }\end{array}$ & $\begin{array}{l}\mathrm{ku} \\
\text { toko }\end{array}$ \\
\hline \multirow[t]{3}{*}{ and } & sing & $\begin{array}{l}\text { ni } \\
\text { niri }\end{array}$ & & & $\begin{array}{l}\text { ciki } \\
\text { ciki }\end{array}$ & $\begin{array}{l}\text { kimi } \\
\text { tiki }\end{array}$ & & & & $\begin{array}{l}\text { na } \\
\text { na }\end{array}$ & $\begin{array}{l}\mathrm{na}(\mathrm{ci}) \\
\mathrm{na}(\mathrm{ci})\end{array}$ & $\begin{array}{l}\mathrm{na}(\mathrm{mi}) \\
\mathrm{na}(\mathrm{mi})\end{array}$ \\
\hline & dual & $\begin{array}{l}\text { nici } \\
\text { nirici }\end{array}$ & & & $\begin{array}{l}\text { ciki } \\
\text { ciki }\end{array}$ & $\begin{array}{l}\text { kimi } \\
\text { tiki }\end{array}$ & & & & $\begin{array}{l}\mathrm{ci} \\
\mathrm{ci}\end{array}$ & $\begin{array}{l}\mathrm{ci} \\
\mathrm{ci}\end{array}$ & $\begin{array}{l}\text { ci } \\
\text { ci }\end{array}$ \\
\hline & plur & $\begin{array}{l}\text { nini } \\
\text { girini }\end{array}$ & & & $\begin{array}{l}\text { ciki } \\
\text { ciki }\end{array}$ & $\begin{array}{l}\text { kimi } \\
\text { tiki }\end{array}$ & & & & $\begin{array}{l}\mathrm{ni} \\
\mathrm{ni}\end{array}$ & $\begin{array}{l}\text { ni(ci) } \\
\text { ni(ci) }\end{array}$ & $\begin{array}{l}\mathrm{ni}(\mathrm{mi}) \\
\mathrm{ni}(\mathrm{mi})\end{array}$ \\
\hline \multirow[t]{3}{*}{$3^{\text {rd }}$} & sing & $\begin{array}{l}\text { ni } \\
\text { niri }\end{array}$ & $\begin{array}{l}\text { saci } \\
\text { saraci }\end{array}$ & $\begin{array}{l}\text { sa } \\
\text { sara }\end{array}$ & $\begin{array}{l}\text { ciki } \\
\text { ciki }\end{array}$ & $\begin{array}{l}\text { kimi } \\
\text { tiki }\end{array}$ & $\begin{array}{l}\text { na } \\
\text { na }\end{array}$ & $\begin{array}{l}\text { naci } \\
\text { naci }\end{array}$ & $\begin{array}{l}\text { nimi } \\
\text { nimi }\end{array}$ & $\begin{array}{l}\text { iu } \\
\text { liu }\end{array}$ & $\begin{array}{l}\mathrm{iu}(\mathrm{ci}) \\
\mathrm{liu}(\mathrm{ci})\end{array}$ & $\begin{array}{l}\mathrm{iu}(\mathrm{mi}) \\
\mathrm{liu}(\mathrm{mi})\end{array}$ \\
\hline & dual & $\begin{array}{l}\text { nici } \\
\text { nirici }\end{array}$ & $\begin{array}{l}\text { saci } \\
\text { saraci }\end{array}$ & $\begin{array}{l}\text { saci } \\
\text { sara }\end{array}$ & $\begin{array}{l}\text { ciki } \\
\text { ciki }\end{array}$ & $\begin{array}{l}\text { kimi } \\
\text { tiki }\end{array}$ & $\begin{array}{l}\text { naci } \\
\text { naci }\end{array}$ & $\begin{array}{l}\text { naci } \\
\text { naci }\end{array}$ & $\begin{array}{l}\text { nimi } \\
\text { nimi }\end{array}$ & $\begin{array}{l}\mathrm{ci} \\
\mathrm{ci}\end{array}$ & $\begin{array}{l}\mathrm{ci} \\
\mathrm{ci}\end{array}$ & $\begin{array}{l}\mathrm{ci}(\mathrm{mi}) \\
\mathrm{ci}(\mathrm{mi})\end{array}$ \\
\hline & plur & $\begin{array}{l}\text { nimi } \\
\text { nirimi }\end{array}$ & $\begin{array}{l}\text { sami } \\
\text { sarami }\end{array}$ & $\begin{array}{l}\text { sami } \\
\text { sarami }\end{array}$ & $\begin{array}{l}\text { ciki } \\
\text { ciki }\end{array}$ & $\begin{array}{l}\text { kimi } \\
\text { tiki }\end{array}$ & $\begin{array}{l}\text { nami } \\
\text { nami }\end{array}$ & $\begin{array}{l}\text { nacimi } \\
\text { nacimi }\end{array}$ & $\begin{array}{l}\text { nimi } \\
\text { nimi }\end{array}$ & $\begin{array}{l}\text { mi } \\
\text { miri }\end{array}$ & $\begin{array}{l}\operatorname{mi}(\mathrm{ci}) \\
\operatorname{miri}(\mathrm{ci})\end{array}$ & $\begin{array}{l}\text { mi } \\
\text { miri }\end{array}$ \\
\hline
\end{tabular}

Illustration 6 (from Allen 1975: 48)

In this paradigm, subject arguments are listed down the left-hand vertical axis, and object arguments across the horizontal axis: where they intersect, the cell contains the non-past (upper line) and past (lower line) suffixes used to signal that specific combination of arguments. These suffixes are added to the relevant verb stem.

A potentially surprising feature in this presentation is that certain cells are left empty: these are the combinations that result in reflexive forms $(1 \mathrm{st}>1 \mathrm{st}$, and 2 nd $>2$ nd) or combinations involving an inclusive and a 2 nd person argument. ${ }^{9}$ In the legend to the table, Allen (1975: 48) provides a brief explanation of the latter type of gap ("Forms expressing interaction between first person inclusive (of audience) and second person (audience) do not occur.") No explicit comment is made in the text surrounding the paradigm about reflexives not being included in the table, nor is the topic discussed in the section on reflexives.

9 Such forms are impossible to generate, and the rare scenarios that might be plausible ("You will kill us all by driving so fast", "Do you see us both in the picture?") are rephrased, often using reflexive forms. 
We see in the matrix-style paradigm adopted by Allen ${ }^{10}$ a new way to present the affixes that mark agreement for Kiranti verbs, with the one axis for each of the two arguments of a transitive verb. This is significantly different from the list paradigms assembled by Hodgson (after testing various formats for presenting the information), where each subject argument was listed with all possible object arguments in turn, and also notably distinct from Toba's paradigm for subject-marking suffixes for Khaling (which did not take into account objectmarking or prefixes ). Allen's paradigm has in fact become the standard layout for presenting Kiranti verbal agreement affixes, and certain features, such as the gaps for reflexives, make it possible to identify this lineage in later grammars.

In his 1987 A grammar of Limbu, G. van Driem explicitly states that there can be more than one argument encoded on the verb: "a simplex [verb] consists of a stem and agreement markers for person and number of the actant or actants involved in the verbal scenario." (1987: 69). He then provides definitions for morphological categories integral to the description of the verbal morphology:

"An agent is the most agentive actant in a transitive verbal scenario and is marked by the ergative suffix. A patient is the less agentive actant in a transitive verbal scenario, which may be the benefiary, vicitim, undergoer or recipient of the action [... ]. An object is a peripheral or least animate third argument in a transitive verbal scenario; it takes no case marker and is not reflected in any verbal agreement markers. A subject is the only actant of an intransitive or reflexive verb and is marked by the absolutive case" (1987: 70)

The three arguments which are encoded on verbs are thus, for transitive verbs, agent and patient, and for intransitive verbs, subject. These are sometimes refered to using the labels $\mathrm{A}, \mathrm{S}$ and $\mathrm{P}$ in the text. ${ }^{11}$

Paradigms are presented in Appendix II ("Paradigms"): analytical paradigms are provided in this section, starting with the transitive verb 'to teach', presenting an analysis of the morphemes involved in person/number combinations of agent and patient for each of four forms: nonpast, non-past negative, past, past negative.

\footnotetext{
${ }^{10}$ When contacted on the question of how he arrived at such a presentation style for paradigms, Allen said that using a matrix with subject in the vertical axis and object in the horizontal, seemed like the most "natural way of presenting the material". (Allen, pc)

${ }^{11}$ But note that the definitions provided for these labels are now a little different, rather than mixing semantic roles (used for transitive arguments) and grammatical relations (used for intransitive arguments).
} 
TRANSITIVE CONJUGATION

$1 \mathrm{~s} \rightarrow 2 \mathrm{~s}$

$\begin{array}{lllll} & h u ? & n \varepsilon & \text { NPT } & \text { sPS sA } \\ & h u ? & n & c & \text { sPS sA } \\ m \varepsilon & h u ? & n \varepsilon & \text { NPT } & \text { sPS sA } \\ m \varepsilon & h u ? & n & c & \text { sPS sA }\end{array}$

$1 s \rightarrow 2 d$

$\begin{array}{lllll} & h u ? & n e & \text { NPT } & \text { tchi } \\ & h u ? & n & c & \text { tchi } \\ m \varepsilon & h u ? & n \varepsilon & \text { NPT } & \text { tchi } \\ m e & h u ? & n & c & \text { tchi }\end{array}$

nen

$1 \mathrm{~s} \rightarrow 2 \mathrm{p}$

$\begin{array}{lllll} & h u ? & n & \text { NPT } & 1 \\ & h u ? & n & \text { PT } & 1 \\ m e & h u ? & n & \text { NPT } & 1 \\ m c & h u ? & n & \text { PT } & 1\end{array}$

nen

nen

$\underline{1 s \rightarrow 3 s}$

\begin{tabular}{|c|c|c|}
\hline & $h u \geqslant r$ & NPT \\
\hline & $h u \geqslant r$ & PT \\
\hline$m \varepsilon$ & hu? & \\
\hline$m \varepsilon-n$ & hu? & \\
\hline
\end{tabular}

SP
SP
SP
SP

$\underline{1 s \rightarrow 3 n s}$

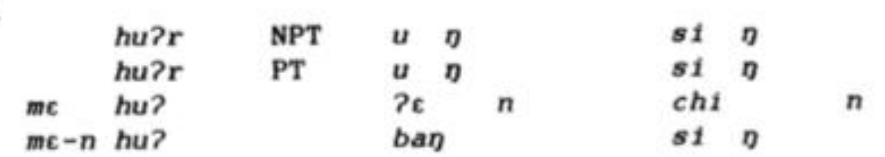

$\begin{array}{llll}\frac{1 d i \rightarrow 3 s}{a} & & h u ? & \text { NPT } s u \\ a & & h u \geqslant r & c \text { tch } u \\ a & n & h u ? & \text { NPT } s \text { u }\end{array}$

a $n$ hupr $c$ tch $u$

$\frac{1 d i \rightarrow 3 n s}{a}$ hu? NPT $s u$

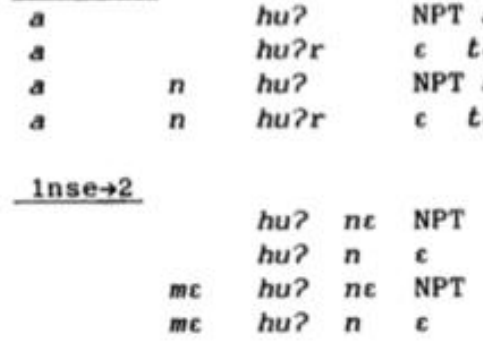

(n)

$\begin{array}{lll}\text { sP } & i & \\ \text { sP } & 1 & \\ \text { sP } & 1 & n \\ \text { sP } & i & n\end{array}$

(n)

$\begin{array}{lll}s 1 & 1 & \\ s 1 & 1 & \\ s i & 1 & n \\ s i & i & n\end{array}$

tchi

tchi

tch1

tchi




Illustration 7 (van Driem 1987: 368)

This type of paradigm, which is a list paradigm in that it lists the various possible combinations of person/number of both arguments (rather than providing a grid), is useful in order to present the analysis of various morphemes and their ordering, as well as seeing permutations caused by tense and negation. Note that a single transitive verb is laid out in this format; Example paradigms for additional transitive verbs are presented in the appendix (p $367 \mathrm{ff}$ ), in which case they are non-analytical list paradigms (as in Ill. 8, for the verb 'to look at', in which the forms in the left column are non-preterite forms, with the negative form under the affirmative; the right column contains preterite forms, again with negative forms under the affirmative for each person/number combination).

\begin{tabular}{|c|c|c|}
\hline \multirow{2}{*}{$1 s \rightarrow 2 s$} & o.motne & o.motne \\
\hline & o.memotnen & o.memotnen \\
\hline \multirow[t]{2}{*}{$1 \mathrm{~s} \rightarrow 2 \mathrm{~d}$} & o.motnetchin & o.motnetchin \\
\hline & o.memotnetchinnen & J.memotnetchinnen \\
\hline \multirow[t]{2}{*}{$1 s \rightarrow 2 p$} & o.motnin & o.motnin \\
\hline & o.memotnipnen & o.memotnipnen \\
\hline \multirow[t]{2}{*}{$1 \mathrm{~s} \rightarrow 3 \mathrm{~s}$} & o.mottun & o.mottun \\
\hline & o.memo?len & כ.memmoppan \\
\hline \multirow[t]{2}{*}{$1 \mathrm{~s} \rightarrow 3 \mathrm{~ns}$} & o.mottunsin & o.mottunsin \\
\hline & o.memo?lenchin & כ.memmoppansin \\
\hline \multirow[t]{2}{*}{$1 \mathrm{di} \rightarrow 3 \mathrm{~s}$} & o. Pamstchu & o. Pamottetchu \\
\hline & 0.2 ammotchun & o. Pammottetchun \\
\hline \multirow[t]{2}{*}{$1 d i \rightarrow 3 n s$} & o. ?amotchusi & o. Tamottetchusi \\
\hline & o. Pammotchus in & J. Pammottetchusin \\
\hline \multirow[t]{2}{*}{ 1nse $\rightarrow 2$} & o.motnetchige & o.motnetchige \\
\hline & o.memotnetchigen & כ.memotne tchigen \\
\hline \multicolumn{3}{|c|}{$\begin{array}{l}\text { Illustration } 8 \text { (van Driem 1987: } 377 \text { ): } \\
\text { verb 'to look at', with left column for non-preterite forms, right column for } \\
\text { preterite forms, with negative forms under affirmative }\end{array}$} \\
\hline
\end{tabular}


The matrix paradigm introduced by Allen reappears in B. Michailovsky's 1988 La langue hayu. Like van Driem, Michailovsky lays out cleary the fact that Hayu verbs index a single argument on intransitives and two arguments on transitives, and he gives them syntactic labels subject and object, used consistently across verb valence types:

"Parmi les arguments d'un verbe dans la proposition, nous identifierons un ou deux "actants" qui sont par définition ici les arguments avec lesquels le verbe s'accorde. Un verbe intransitif à l'indicatif ou à l'impératif s'accorde en personne et en nombre avec un actant, qu'on appelera le sujet. [...] Un verbe transitif s'accorde, avec plus ou moins de précision selon leur personne et leur nombre, avec deux actants, que nous appellerons ici sujet et objet." (1988: 79)

When paradigms are introduced, there is an explicit description of how they are put together: "Le tableau est construit avec la personne et le nombre du sujet sur l'axe vertical, et de l'objet sur l'axe horizontal. On fera référence aux différents suffixes (ou formes verbales) par leurs coordonnées : d'abord le sujet, suivi d'une flèche, puis l'objet. Par exemple, les coordonnées $2 S \rightarrow 1 S$ 'sujet de la deuxième personne du singulier, objet de la première personne du singulier'." (1988: 81) 
Lègende :

Non-passé
passe applicatif *



\section{Sujet:}

IDE

IDI

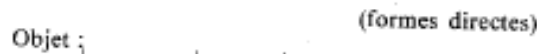

tship

kok tikok

IPE

kikon tikon

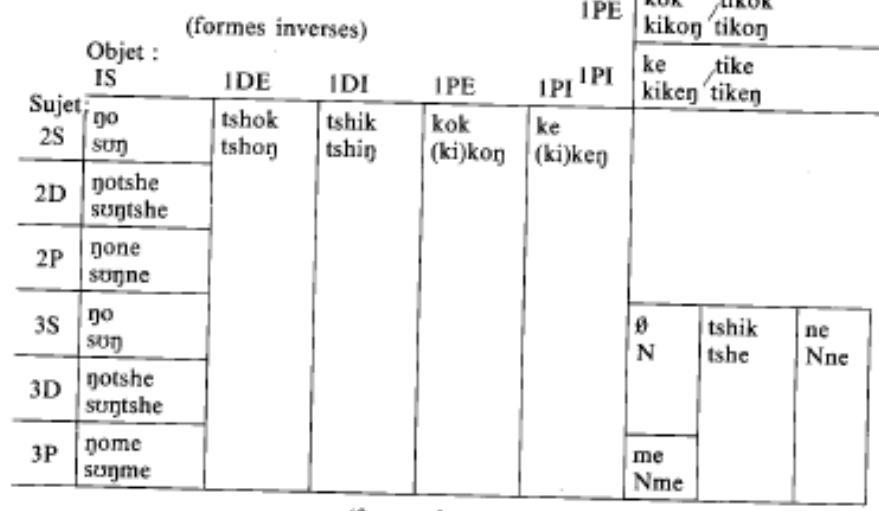

(formes inverses)



(formes directes)

- Avec les racines en $-/(t) /(3,71)$ les suffixes de l'applicatif ne sont utilisés qu'au passé.

Illustration 9. Affix table for transitive verbs (Michailovsky 1988: 82)

As seen in illustration 9, person/number combinations are identified throughout the table as 'sujet' or 'objet', and different areas of the paradigms are identified as containing either inverse or direct forms. The gaps in Allen's paradigm for reflexive forms (in other words $1>1$ and $2>2$ ) are here left out of the paradigm by drawing cells only around combinations that are found.

In Michailovsky, we thus find consistent use of labels for the arguments indexed on the verb, clear explanations on how the paradigm is put together and to be used, and a creatively drawn paradigm which makes it possible to avoid mention of the gaps formed where reflexive forms are expected. From this point on, all descriptions of Kiranti verbal morphology will make use of matrix paradigms (sometimes in addition to list paradigms) and, as we shall see, explanations will not necessarily be provided for the paradigm, suggesting that authors after Michailovsky take the layout of the paradigm to be either natural (following Allen's intuition) or well-established enough to be self-explanatory. 
In A grammar of Jero, by J.R. Opgenort (2005), we return to the terminology used by van Driem ${ }^{12}$ for the arguments indexed on verbs: "The notion of transitivity has bearing on the core arguments (subject, agent, patient) that are cross-referenced in the finite verb." (2005: 126) Even though these terms combine semantic and syntactic notions on the basis of verb valence, they have spread through grammars of Kiranti languages, probably due to the prevalence in Kiranti studies of team members of the Leiden school headed by van Driem. ${ }^{13}$

As far as verb paradigms are concerned, Opgenort chooses a layout very similar to Michailovsky's (with the practical difference that it is split into two parts (first person patients vs second and third person patients) in order to fit the page format of the grammar). Differences are that the paradigm is not as clear as Michailovsky's about which are the 'agent' and which the 'patient' person/number combinations $^{14}$, nor are the inverse and direct parts of the paradigm identified in so many words. It is however very similar to Michailovsky's paradigm in that the reflexive and (new here) $2<>1$ inclusive are not as empty cells but rather the paradigm is drawn so as not to include those cells.

12 Significantly, Opgenort's grammar is his doctoral dissertation, which was supervised by van Driem.

${ }_{13}$ In my dissertation (Lahaussois 2002), I adopted the same system of intransitive 'subject' vs transitive 'agent' and 'patient', without considering that it wasn't the best possible distribution of terms across arguments.

14 But note the symbols AlP in upper left-hand cell, and that the lessened explicitness is a sign of the establishment of the conventions Michailovsky uses. 


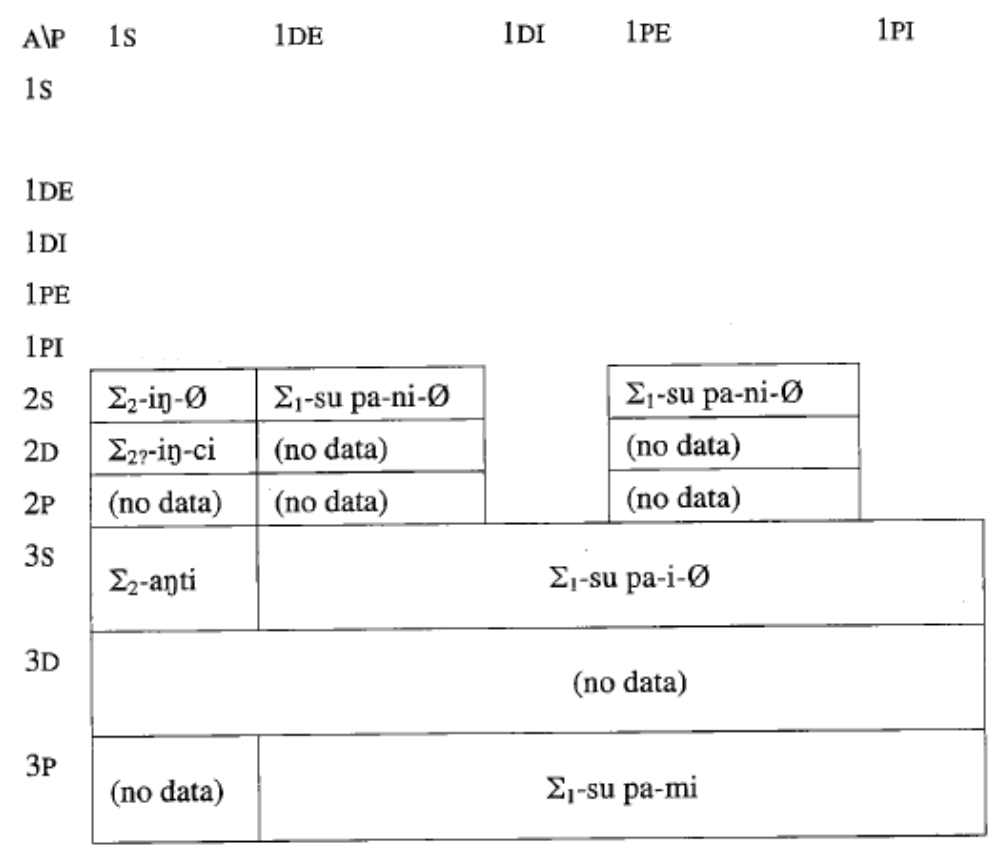

Diagram 15: Mohanțāre Jero transitive conjugation (first person patients)

\begin{tabular}{|c|c|c|c|c|c|c|}
\hline$A \backslash P$ & $2 \mathrm{~s}$ & $2 \mathrm{D}$ & $2 \mathrm{P}$ & $3 \mathrm{~s}$ & $3 \mathrm{D}$ & $3 P$ \\
\hline 1s & \multirow{2}{*}{$\Sigma_{2}$-ni- $\varnothing$} & $\Sigma_{2 ?-\text { ni-ci }}$ & $\Sigma_{2 \text { ? }}$ ni-ni & \multirow{2}{*}{$\Sigma_{1}-\mathfrak{n u}$} & $\Sigma_{1}$-nu-ci-mi & $\Sigma_{1}$-nu-mi \\
\hline & & \multicolumn{2}{|c|}{$\Sigma_{1}$-su pa-nu } & & & \\
\hline $1 \mathrm{DE}$ & \multicolumn{3}{|c|}{ (no data) } & $\Sigma_{2}-\mathrm{cu}$ & \multicolumn{2}{|c|}{ (no data) } \\
\hline IDI & & & & \multicolumn{3}{|c|}{$\Sigma_{2}$-ci } \\
\hline $1 \mathrm{PE}$ & \multicolumn{2}{|c|}{ (no data) } & $\Sigma_{1}$-su po-ku & $\Sigma_{2}-\mathrm{ku}$ & \multicolumn{2}{|c|}{ (no data) } \\
\hline 1PI & & & & \multicolumn{3}{|c|}{$\Sigma_{2}-\mathrm{ki}$} \\
\hline $2 s$ & & & & \multicolumn{3}{|c|}{$\Sigma_{1}-\mathrm{ni}-\varnothing$} \\
\hline $2 \mathrm{D}$ & & & & $\Sigma_{2}$-ci & \multicolumn{2}{|c|}{ (no data) } \\
\hline $2 \mathrm{P}$ & & & & $\Sigma_{2}$-ni-mi & \multicolumn{2}{|c|}{ (no data) } \\
\hline $3 s$ & $\Sigma_{2}$-nati & $\Sigma_{2}$-ci-mi & $\Sigma_{2}$-ni-mi & \multicolumn{3}{|c|}{$\Sigma_{1-i-Ø}$} \\
\hline $3 D$ & $\Sigma_{2 ? \text {-ci-mi }}$ & (no data) & (no data) & $\Sigma_{1}$-i-ci-? & \multicolumn{2}{|c|}{ (no data) } \\
\hline $3 \mathrm{P}$ & (no data) & (no data) & (no data) & \multicolumn{3}{|c|}{$\Sigma_{1}$-mi } \\
\hline
\end{tabular}

Diagram 15 continued: Mohantạ̄re Jero transitive conjugation (second and third person patients) 
Illustration 10 (Opgenort 2005: 144-145)

Because full paradigms occupy a lot of space, and because of the difficulty in obtaining all the forms needed for a full matrix paradigm, Opgenort mostly resorts to what we have refered to as list paradigms, of the sort already seen in the work of Hodgson and van Driem. Note that in the case of the following list paradigm (for the verb 'can'), only 3SG objects are given with the different subject possibilities:

$\begin{array}{lll}\mathrm{A} \rightarrow \mathrm{p} & \text { phaccap } & \text { pleccam } \\ 1 \mathrm{~s} \rightarrow 3 \mathrm{~s} & \text { phapma } & \text { ple?ma } \\ 2 \mathrm{~s} \rightarrow 3 \mathrm{~s} & \text { phamim } & \text { plenim } \\ 3 \mathrm{~s} \rightarrow 3 \mathrm{~s} & \text { phattim } & \text { plettim } \\ 1 \mathrm{di} / 2 \mathrm{~d} \rightarrow 3 \mathrm{~s} & \text { phancim } & \text { plencim } \\ 1 \mathrm{de} \rightarrow 3 \mathrm{~s} & \text { phancum } & \text { plencum } \\ 3 \mathrm{~d} \rightarrow 3 \mathrm{~s} & \text { phaccim } & \text { plecikm } \\ 1 \mathrm{pi} \rightarrow 3 \mathrm{~s} & \text { phaykim } & \text { pleykim } \\ 1 \mathrm{pe} \rightarrow 3 \mathrm{~s} & \text { phankum } & \text { plenkum } \\ 2 \mathrm{p} \rightarrow 3 \mathrm{~s} & \text { phannimme } & \text { plenimme } \\ 3 \mathrm{p} \rightarrow 3 \mathrm{~s} & \text { pha:?me } & \text { ple?imme } \\ & & \\ 2 \mathrm{~s} \rightarrow 3 \mathrm{~s} \text { IMP } & \text { krakka } & \text { plekkha } \\ 2 \mathrm{~d} \rightarrow 3 \mathrm{~s} \text { IMP } & \text { krakkaci } & \text { plekkhaci } \\ 2 \mathrm{p} \rightarrow 3 \mathrm{~s} \text { IMP } & \text { krakkani } & \text { plekkhani } \\ & & \end{array}$

In his 2009 A Grammar of Bantawa, Doornenbal reprises the terminology initiated by van Driem for verb arguments, namely subject, agent and patient. ${ }^{15}$ The use of the terminology is, however, explained in detail in Chapter 6 'Transitivity Operations': "In action verbs, from a semantic point of view, the subject can have roles ranging from passive patient to active agent".... "For a normal transitive verb, the action can be pictured as originating from the agent and affecting the patient, say $\mathrm{A} \rightarrow \mathrm{P}$. The normal case if where the syntactic and semantic roles of the participants coincide." (2009: 211)

Three different types of paradigms are presented in Doornenbal's work: a schematic paradigm showing possible argument combinations; a matrix

${ }^{15}$ Like Opgenort's, Doornenbal's grammar was written as a doctoral dissertation under the supervision of G. van Driem. 
paradigm for transitive verbs, abstracted by using $\Sigma$ to stand in for the verb root; list paradigms showing actual forms found for different person/number combinations of both arguments (and at the same time, showing the different verb stems that alternate across the paradigms).

The schematic paradigm (Ill. 12) makes it possible to explain the how to interpret the paradigmatic data, and it is accompanied by text which which makes clear what the symbols represent: "a first person agent acts upon a second person patient $(1 \rightarrow 2)$, and so on." (ibid. 143) Doornenbal also specifies, in the text presenting the paradigm, that reflexives are not found: "forms of $1 \rightarrow 1$ and $2 \rightarrow 2$ are expressive by reflexive forms, so these are not found in the transitive paradigm table." (ibid. 145)

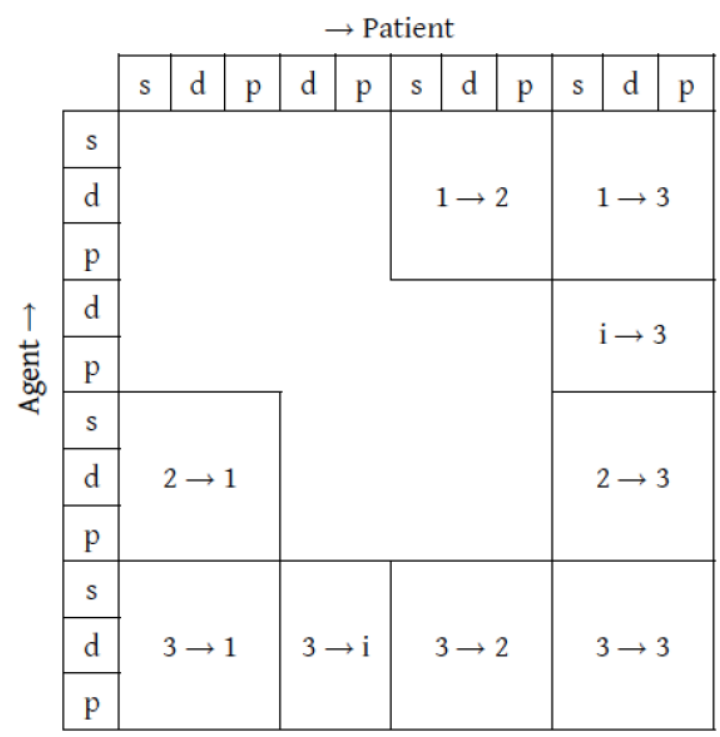

Illustration 12 (Doornenbal 2009: 146)

The schematic paradigm is followed by a transitive paradigm with affixes for all possible argument combinations. Note that this presentation is slightly different from matrix paradigms in Michailovsky and Opgenort in that it is closed: the paradigm includes areas which are empty, and must thus be explained. Additionally, 'ID' and 'IP' here refer to inclusive dual and plural arguments, and by separating them out from ' $1 \mathrm{D}^{\prime}$ and ' $1 \mathrm{P}^{\prime}$ ' 1 st dual and plural exclusive respectively), the empty areas of the paradigm stand out less clearly. While the A/P tag in the upper left-hand corner ensures that the paradigm is 
interpreted correctly, the schematic paradigm, which is presented a few pages earlier in the grammar, has already set the stage for ease of use.

\begin{tabular}{|c|c|c|c|c|c|c|c|c|c|c|}
\hline $\mathrm{A} / \mathrm{P}$ & $1 \mathrm{~s}$ & 1D & $1 \mathrm{P}$ & ID & IP & $2 \mathrm{~s}$ & $2 \mathrm{D}$ & $2 \mathrm{p}$ & $3 s$ & $3 \mathrm{NS}$ \\
\hline $1 \mathrm{~s}$ & & & & & & $\Sigma$-na & $\sum$-naci & $\Sigma$-nanin & $\Sigma$-un & $\Sigma$-uycin \\
\hline 1D & & & & & & \multirow{2}{*}{\multicolumn{3}{|c|}{$\Sigma$-ni }} & $\Sigma$-cu?a & $\Sigma$-cuci?a \\
\hline $1 \mathrm{P}$ & & & & & & & & & $\Sigma$-umka & $\Sigma$-umcimka \\
\hline ID & & & & & & & & & $\Sigma$-cu & $\Sigma$-cuci \\
\hline IP & & & & & & & & & $\Sigma$-um & $\Sigma$-umcim \\
\hline $2 \mathrm{~s}$ & ti- $\Sigma$-na & \multirow{3}{*}{\multicolumn{2}{|c|}{ ti- $\Sigma$-ni(n) }} & & & & & & $\mathrm{ti}-\Sigma-\mathrm{u}$ & ti- - -uci \\
\hline $2 \mathrm{D}$ & ti- $\Sigma$-naycin & & & & & & & & ti- $\Sigma$-cu & ti- $\Sigma$-cuci \\
\hline $2 \mathrm{p}$ & ti- $\Sigma$-yannin & & & & & & & & ti- - -um & ti- $\Sigma$-umcum \\
\hline $3 \mathrm{~s}$ & $i-\Sigma-\eta a$ & (n)i- - -aci?a & (n)i- $\Sigma$-inka & \multirow{3}{*}{$\mathrm{n} \dot{-}-\Sigma-\mathrm{ci}$} & \multirow{3}{*}{$\mathrm{mi}-\Sigma$} & \multirow{3}{*}{$n i-\Sigma$} & \multirow{3}{*}{$n i-\Sigma-c i$} & \multirow{3}{*}{$n i-\Sigma-i n$} & $\Sigma$-u & $\Sigma$-uci \\
\hline $3 \mathrm{D}$ & $i-\Sigma$-yancin & \multirow{2}{*}{ ni-E-aci?a } & \multirow{2}{*}{ ni- $\Sigma$-inka } & & & & & & $i-\Sigma$-cu & $i$ - $\Sigma$-cuci \\
\hline $3 \mathrm{P}$ & ni- $\Sigma-\eta a$ & & & & & & & & $i-\Sigma$ & mi- $\Sigma$-uci \\
\hline
\end{tabular}

Non-past Affirmative Transitive Paradigm

Illustration 13 (Doornenbal 2009: 148)

The appendix includes a number of list paradigms, with all possible argument combinations, the format presumably chosen as a typographically more compact way of presenting the data. One partial example can be seen in Illustration 14. 


\section{B.9 'To take'}

\begin{tabular}{|c|c|c|c|}
\hline & Non-past affirmative & & Non-past negative \\
\hline $1 \mathrm{~s} \rightarrow 2 \mathrm{~s}$ & $\mathrm{k}^{\mathrm{h}}$ atna & $1 \mathrm{~s} \rightarrow 2 \mathrm{~s}$ & $i \mathrm{k}^{\text {hatnan }}$ \\
\hline $1 s \rightarrow 2 d$ & $\mathrm{k}^{\mathrm{h}}$ atnaci & $1 \mathrm{~s} \rightarrow 2 \mathrm{~d}$ & $\mathrm{ik}^{\text {h }}$ atnancin \\
\hline $1 \mathrm{~s} \rightarrow 2 \mathrm{p}$ & $\mathrm{k}^{\text {h }}$ atnanin & $1 \mathrm{~s} \rightarrow 2 \mathrm{p}$ & $i \mathrm{k}^{\text {hatnaminin }}$ \\
\hline $1 \mathrm{~s} \rightarrow 3 \mathrm{~s}$ & $\mathrm{k}^{\mathrm{h}}$ attur & $1 \mathrm{~s} \rightarrow 3 \mathrm{~s}$ & $i k^{h}$ atnin \\
\hline $1 \mathrm{~s} \rightarrow 3 \mathrm{~ns}$ & $\mathrm{k}^{\text {hattuycin }}$ & $1 \mathrm{~s} \rightarrow 3 \mathrm{~ns}$ & $i \mathrm{k}^{\text {hatnincin }}$ \\
\hline $1 \mathrm{~d} \rightarrow 2 \mathrm{~s}$ & $\mathrm{k}^{\mathrm{h}}$ atni & $1 \mathrm{~d} \rightarrow 2 \mathrm{~s}$ & $i k^{h}$ atnin \\
\hline $1 \mathrm{~d} \rightarrow 3 \mathrm{~s}$ & $\mathrm{k}^{\mathrm{h}}$ atcu?a & $1 \mathrm{~d} \rightarrow 3 \mathrm{~s}$ & $\mathrm{ik} \mathrm{k}^{\mathrm{h}}$ atcunka \\
\hline $1 \mathrm{~d} \rightarrow 3 \mathrm{~ns}$ & $\mathrm{k}^{\mathrm{h}}$ atcuci?a & $1 \mathrm{~d} \rightarrow 3 \mathrm{~ns}$ & $i \mathrm{k}^{\mathrm{h}}$ atcuncinka \\
\hline $1 \mathrm{p} \longrightarrow 3 \mathrm{~s}$ & $\mathrm{k}^{\text {h}}$ attumka & $1 \mathrm{p} \rightarrow 3 \mathrm{~s}$ & $\mathrm{ik} \mathrm{k}^{\mathrm{h}}$ ttiminka \\
\hline $1 \mathrm{p} \longrightarrow 3 \mathrm{~ns}$ & $\mathrm{k}^{\text {hattumcimka }}$ & $1 \mathrm{p} \rightarrow 3 \mathrm{~ns}$ & $i \mathrm{k}^{\mathrm{h}}$ attimincinka \\
\hline $\mathrm{id} \rightarrow 3 \mathrm{~s}$ & $\mathrm{k}^{\mathrm{h}}$ atcu & id $\rightarrow 3 \mathrm{~s}$ & $\mathrm{ik}^{\mathrm{h}}$ atcun \\
\hline $\mathrm{id} \rightarrow 3 \mathrm{~ns}$ & $\mathrm{k}^{\text {h}}$ atcuci & id $\rightarrow 3 \mathrm{~ns}$ & ikhatcuncin \\
\hline $\mathrm{ip} \longrightarrow 3 \mathrm{~s}$ & $\mathrm{k}^{\mathrm{h}}$ attum & $\mathrm{ip} \rightarrow 3 \mathrm{~s}$ & $\mathrm{ik} \mathrm{k}^{\mathrm{h}}$ attimin \\
\hline $\mathrm{ip} \rightarrow 3 \mathrm{~ns}$ & $\mathrm{k}^{\mathrm{h}}$ attumcim & ip $\rightarrow 3 \mathrm{~ns}$ & $\mathrm{ik}^{\mathrm{h}}$ attimincin \\
\hline $2 s \rightarrow 1 s$ & tikhatrya & $2 s \rightarrow 1 s$ & tikhatnin \\
\hline $2 s \rightarrow 1 d$ & tik $^{\text {hatni(n) }}$ & $2 s \rightarrow 1 d$ & tik ${ }^{h}$ atniminin \\
\hline $2 s \rightarrow 3 s$ & tik hattu & $2 s \rightarrow 3 s$ & tik hatnan \\
\hline $2 \mathrm{~s} \rightarrow 3 \mathrm{~ns}$ & tik hattuci & $2 \mathrm{~s} \rightarrow 3 \mathrm{~ns}$ & tik $k^{h}$ atnancin \\
\hline
\end{tabular}

In Schackow's 2015 A Grammar of Yakkha, the terms we find in reference to arguments are mostly syntactic - subject and object—, sometimes used alongside macro-role abbreviations S, A and P. We find a single type of transitive paradigm in this grammar (although templates are used for the linear ordering of morphemes): the matrix paradigm. This type of paradigm is used for the presentation on a number of occasions to present complete verbal data (the actual forms resulting from root+affix combinations). The first presentation of a matrix paradigm in the grammar contains only affixes, and its use is explicited textually with an example: "third person acting on second person $(3>2)$ " (ibid. 217 ), ensuring that the "A>P" and the axes for subject and object are interpreted correctly. 
Table 8.11: Indicative person/number marking (intransitive and transitive)

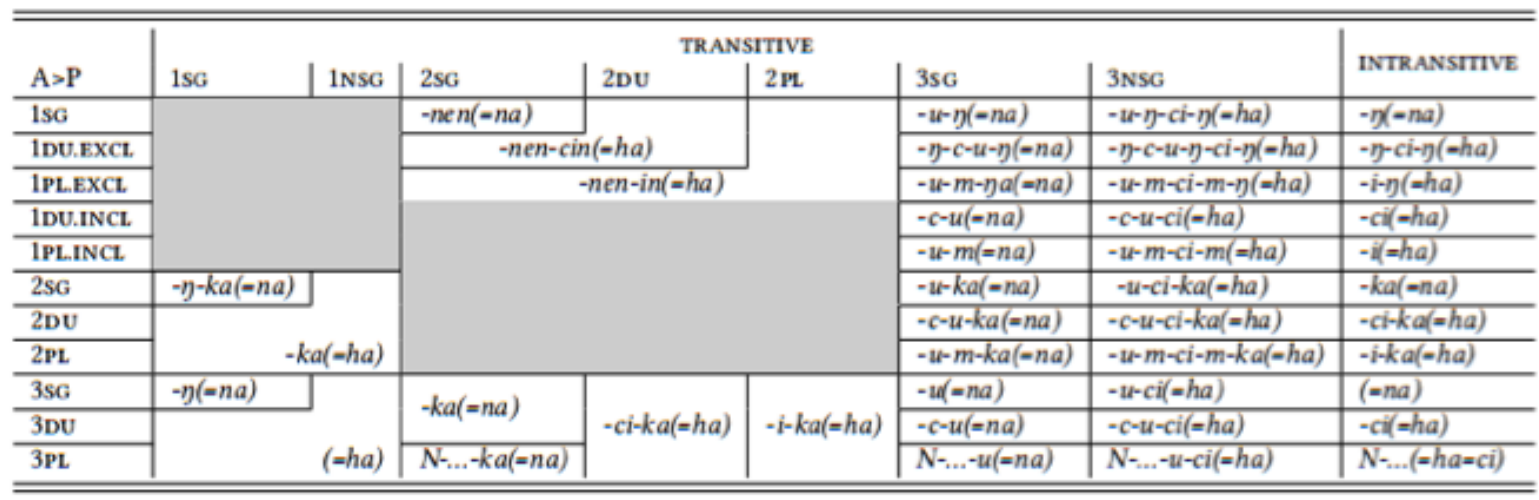

Illustration 14 (Schackow 2015: 218)

There is also mention of the reflexive construction which is needed for certain combinations, thus explaining presence of empty slots (2015: 227).

One new feature in this paradigm layout, compared to the others seen before this, is the presence of intransitive affixes lined up against the transitive ones. This is something that is also found in Bickel's16 work on Belhare (2003: 551-552), and makes it possible to trace the parallels between the affixes used to mark the $\mathrm{S}$ argument of intransitives and the $\mathrm{P}$ argument in transitives. Note that the paradigm presentation found in Schackow (via Bickel) is potentially traceable back to Bickel's supervisor Karen Ebert: in her grammar of Athpare (1997), she makes explicit reference to van Driem's presentations, which she follows, 1997: 30, but also Ebert inserts intransitive affixes into the transitive paradigm as an additional column on the right (ibid, 31). ${ }^{17}$

Another innovation is to be found in the abstracted paradigms that Schackow provides to show the alignement of person/number markers across the paradigms (see Ill. 15). These paradigms also show the intransitive markings (the $\mathrm{S}$ column for each matrix), and make it possible to see how various markers match up with respect to role, as well as number and person. ${ }^{18}$

\footnotetext{
${ }^{16}$ Again, note that Schackow's dissertation, which is the source for her grammar, was supervised by Bickel at Zurich.

17 Note that all other authors whose work is presented in this article handle intransitive paradigms separately from transitive ones.

${ }_{18}$ Considering the elegance of this presentation, I would not be surprised to see it used in subsequent Kiranti grammars by different authors.
} 


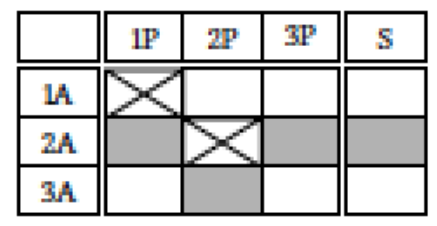

$+k a \cdot 2$ ' (neutral, except 1>2)

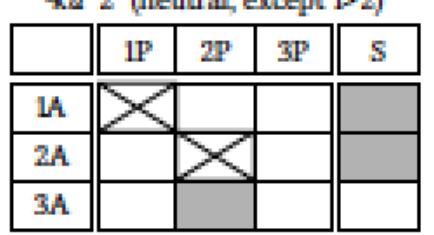

'1/2pl.S' 8 ' $2 \mathrm{P}^{\prime}$ (ergative for 2, except

\begin{tabular}{|c|c|c|c|c|}
\hline \multicolumn{5}{|c|}{$1>2)$} \\
\hline & IP & $2 P$ & $3 \mathrm{P}$ & s \\
\hline $\mathrm{IA}$ & & & & \\
\hline $2 \mathrm{~A}$ & & & & \\
\hline $3 A$ & & & & \\
\hline
\end{tabular}

$-u$ '3P', -ci '3nsg. P' (accusative)

\begin{tabular}{|c|c|c|c|}
\hline & IP & $2 P$ & $3 P$ \\
\hline $\mathrm{IA}$ & & & \\
\hline $2 \mathrm{~A}$ & & & \\
\hline $3 A$ & & & \\
\hline
\end{tabular}

$-m \mathrm{~m}^{2} 1 / 2 \mathrm{pl}>3^{\prime}$ (scenario-portmanteau)

\begin{tabular}{|c|c|c|c|c|}
\hline & $\mathbb{I P}$ & $2 P$ & $3 P$ & $S$ \\
\hline IA & & & & \\
\hline $2 \mathrm{~A}$ & & & & \\
\hline $3 \mathrm{~A}$ & & & & 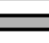 \\
\hline
\end{tabular}

$-c{ }^{2}$ dual' (mixed: acc./neutrall/ref.-based)



$-\mathrm{g}(\mathrm{a})$ 'excl, 1se' (neutral, execpt 1>2)

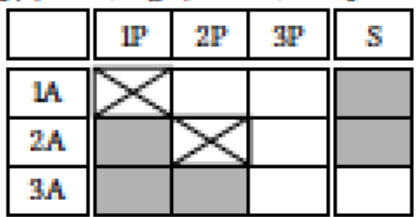

Histarical forms (recent loss of Insg P forms): $-i$ ' $1 / 2 \mathrm{pl} . S / \mathrm{P}^{\prime}$ (ergative)

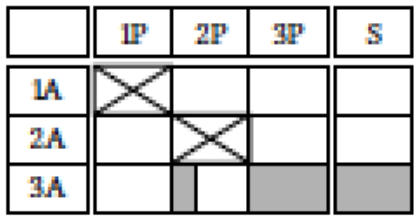

$N$ - '3pl.S/A', zero '3ag S/S/A' (accusative)

\begin{tabular}{|l|l|l|l|l|}
\hline & $\mathbb{P}$ & $2 \mathrm{P}$ & $3 \mathrm{P}$ & $\mathrm{S}$ \\
\hline $\mathrm{IA}$ & $\mathbf{X}$ & & & \\
\hline $2 \mathrm{~A}$ & & $\mathrm{X}$ & & \\
\hline $3 \mathrm{~A}$ & & & & \\
\hline
\end{tabular}

-nen ' $1>2$ ' (scenario-portmanteau)

\begin{tabular}{|l|l|l|l|l|l|}
\hline & IP & 2P & 3P & $S$ \\
\hline \hline IA & & & & & \\
\hline $2 A$ & & & & & \\
\hline $3 A$ & & & & \\
\hline
\end{tabular}

-na 'sg'; - ha 'nsg' (miwed: erg/ref.-baved)

Illustration 15 (Schackow 2015: 228)

\section{CONCLUSION}


While Hodgson had clearly identified the feature of bipersonal indexation in Hayu and Bahing, and made headway towards presenting the data in concise paradigmatic form "accommodated to the genius of the language" (1857: 470), we have seen that there were a number of different layouts across grammars until Allen established the matrix-style Kiranti verb paradigm that is widely used today.

One interesting phenomenon in retracing the evolution of the shapes used to represent transitive paradigms in these languages is how the lineages become apparent: the influences of dissertation supervisors become apparent in the terminology used to refer to arguments, as well as the layouts that are used (such as list paradigms, matrix paradigms, inclusion of intransitive data) and the modifications made to such formats from one author to another. This suggests that it is relevant to speak of grammaticographical "schools" for Kiranti languages, this being a topic which needs further investigation in terms of how the school in question affects the topics treated in the grammar (see Lahaussois 2016, 2018, Kelly and Lahaussois ms.). To this we must of course add the influence of prevailing linguistic theory at the time of the grammar's publication.

It is quite clear that there is much to be learned about the extension of grammatical models by looking at something as representational as a verb paradigm: even with the set parameters (expression of two arguments via affixal morphology), there is room for variation and innovation, and the textual explicitation (or absence thereof) of how the paradigm is assembled and to be used can also tell us a great deal about how deeply ingrained the areal tradition of a certain general presentation style is felt to be.

\section{REFERENCES}

Allen, N. 1975, Sketch of Thulung Grammar, Ithaca, N.Y.

Bickel, B. 2003, Belhare, In Graham Thurgood and Randy LaPolla, The SinoTibetan Languages, London: Routledge. (Routledge Language Family Series 3) p. 546-570.

Doornebal, M. 2009, A Grammar of Bantawa, PhD Dissertation, Leiden University.

Driem, van, G. 1987, A Grammar of Limbu, Berlin: Mouton de Gruyter.

Ebert, Karen. 1997. A grammar of Athpare. Lincom Studies in Asian Linguistics 1, Muenchen: Lincom

Eliot, J. 1666, The Indian Grammar begun: or, An essay to bring the Indian language into rules, for the help of such as desire to learn the same, for the furtherance of the Gospel among them, Cambridge: Marmaduke Johnson, Online: https://archive.org/details/grammarofmassach00elio

Hodgson, BH. 1857, Bahing Vocabulary, Journal of the Asiatic Society of Bengal 26:486-522, https://archive.org/details/in.ernet.dli.2015.281604

Hodgson, BH. 1857, Vayu Vocabulary, Journal of the Asiatic Society of Bengal 26:372-485, Online: https://archive.org/details/in.ernet.dli.2015.281604

Hodgson, BH. 1858, Bahing Vocabulary, Journal of the Asiatic Society of Bengal 27:393-442, Online: https://archive.org/details/journalofasiatic27asia 
Jacaues. G.. Lahaussois. A.. Michailovskv. B.. \& Rai. D. B. 2012. "An overview of Khaling verbal mornhologv", Language and Linguistics 13.6, 1095-1170.

Kelly, B. \& Lahaussois, A. ms. Chains of influence in Himalayan grammars: models and interrelations shaning descrintions of TB languages of Nenal.

Lahaussois. A. 2002. Asnects of the grammar of Thulung Rai: an endangered Himalayan language. Universitv of California. Berkelev. $390 \mathrm{p}$

Lahaussois. A. 2016. "Where have all the interiections gone? A look into the nlace of interiections in contemnorarv grammars of endangered languages." In Assuncão. Carlos. Goncalo Fernandes \& Rolf Kemmler (eds) Tradition and Innovation in the Historv of Linguistics: Contributions from the 13th International Conference on the Historv of the Language Sciences (ICHoLS XIII). Vila Real. 25-29 August 2014. Münster: Nodus Publikationen.

Lahaussois. A. 2017. Ideonhones in Khaling Rai. Languages of the TibetoBurman Area, 40:2, 179-201.

Michailovsky, B. 1988, La langue Науu, Paris: Editions du CNRS.

Opgenort, JR. 2005, A Grammar of Jero with a historical comparative study of the Kiranti languages, Leiden: Brill.

Pike, K. 1962, Dimensions of Grammatical Constructions, Language, 38:3, 221-244.

Schackow, D. 2015, A Grammar of Yakkha, Berlin: Language Science Press (Studies in Diversity Linguistics, 7)

Toba, I. 1973, The Khaling Verb, Collected papers on Khaling, Kulunge, Darai, Newari, Chitwan Tharu. Nepal Studies in Linguistics I:1-14.

Yadav, R. 1996, A Reference Grammar of Maithili, Berlin/New York: Mouton de Gruyter (Trends in linguistics: Documentation 11) 